\title{
SEASONAL EFFECTS OF FEEDING ON THE ULTRASTRUCTURE OF THE RUMINAL MUCOSA EPITHELIUM AND RUMINAL BACTERIA IN THE FALLOW-DEER (Dama dama L.)
}

\author{
J. KOČIŠOVÁ, E. TOMAJKOVÁ ${ }^{1}$, J. KOČIŠ ${ }^{1}$ \\ Institute of Animal Physiology, Slovak Academy of Sciences, 04001 Košice, \\ ${ }^{1}$ University of Veterinary Medicine, 04001 Košice Slovak Republic.
}

Received July 19, 1995

\begin{abstract}
Kočišová J., E. Tomajková, J. Kočis: Seasonal Effects of Feeding on the Ultrastructure of the Ruminal Mucosa Epithelium and Ruminal Bacteria in the Fallow Deer (Dama dama L). Acta vet. Brno 1995, 64:231-234.

The multilayered epithelium of ruminal mucosa in fallow-deer was investigated in the course of four seasons of the year. A total of 16 animals was studied, with 4 individuals in each group. Except for winter when they were offered additional feed, the animals grazed. Excisions of ruminal mucosa were processed using the routine methods for electronmicrospical study. Cells of the multilayered epithelium were compared within experimental groups (spring, summer, autumn, winter). Each layer of the epithelium consisted of typical cells (basal, parabasal, intermediary, granular, transitional, keratinized). Intercellular spaces of different widths were found in individual layers and groups of animals. The widest spaces were found in the basal layer in the groups spring and summer.

Cytoplasmic projections of adjoining cells were connected by desmosomes. Mitochondria, indicators of metabolic processes, were most numerous in the basal and intermedial cells in animals studied in the spring and summer. A continuous layer of transitional cells was found in summer and partially in spring. Ruminal bacteria were found to adhere to the surface of keratinized cells and also among ther cells. It is concluded that the observed seasonal changes in ruminal mucosa of the fallow deer are a result of mucosal adaptation to various types of diets.
\end{abstract}

Electron microscopy, multilayered epithelium, rumen, fallow-deer, seasonality

In ruminants, the rumen remains to be an interesting object of study not only for biochemists and microbiologists but also for morphologists, above all at the level of ultrastructure of the mucosal epithelium. To our knowledge, the data on seasonal effects upon this epithelium have not been known to detail though certain changes have been suggested. Even less information than on domestic ruminants is available on wild ruminants such as the various deer species. Therefore the aim of our study was to investigate the epithelium of the ruminal mucosa in fallow deer in the course of the year, under different feeding conditions.

The ruminal mucosal epithelium is multilayered, therefore we aimed at the differences in individual types of cells. Besides its food storage function, the rumen also shows high absorptive and secretory activities (B arcroft et al. 1944). Morphological findings are in good agreement with these activities (e. g., Kočišová and Belák 1973; Belák and Kočišová 1973; Schnorr and Vollmerhaus 1967).

\section{Materials and Methods}

Fallow-deer aged 2-9 years were used in our experiment. The animals moved freely around a grassland deerpark, they grazed a meadow mixture with white clover, and in winter they were offered hay, alfalfa, apples and beets. In each season of the year, four animals were killed. Samples were collected in March, July, October and January. For the electron microscopical study, excisions of the ruminal mucosa of the dorsal sac were fixed in $3 \%$ glutaraldehyde in $0.1 \mathrm{M}$ buffered phosphate solution, postfixed in $1 \% \mathrm{OsO}_{4}$, dehydrated in increasing ethanol 
series, saturated with embedding media and lastly embedded into Durcupan. The ultrathin sections were contrasted with uranyl acetate (W a t s on 1958) and lead citrate (R e y nold s 1963) and examined with an electron microscope JEM $1200 \mathrm{EX}$ at the accelerating voltage of $80 \mathrm{kV}$.

\section{Results}

Ultrastructure of the epithelium of ruminal mucosa in spring The layered epithelium of ruminal mucosa consisted of basal, parabasal, intermediary, granular, transitional and keratinized cells (Schnorr and Vollmerhau s 1967). The basal layer consisted of high cylindrical basal cells with numerous mitochondria (Fig. 1) situated in the supranuclear zones of the cells. Numerous finger-like projections of basal and parabasal cells reached into wide intercellular spaces. The intermediary cells (Fig. 3) contained large numbers of mitochondria in the cytoplasm as well as finger-like projections in wide intercellular spaces. The granular cell layers were already flattened. Preserved desmosomes ensured connection of two adjoining cells. The layer of transitional cells (Fig. 4) forming a transitional layer between granular and keratinized cells typically contained vacuoles filled with so-called ER protein (Lavker and Mat ol t s y 1970). These cells play a role in the metabolic processes in the rumen. Dendritic cells were found sporadically. Under the layer of keratinized cells as well as on their surface whole colonies of ruminal bacteria and protozoa were found (Fig. 5).

Ultrastructure of the epithelium of ruminal mucosa in summer The epithelium of ruminal mucosa showed no conspicuous changes in individual types of cells as compared with the previous group. Only wider intercellular spaces in the basal layer of the epithelium as well as a greater number of mitochondria in the cytoplasm were recorded. These intercellular spaces were considerably widened and contained numerous projections of basal and parabasal cells (Fig. 2). Similarly, a continuous layer of transitional cells was found. Desmosomes connected granular and keratinized cells.

Ultrastructure of the epithelium of ruminal mucosa in a tumn

Compared to summer findings, intercellular spaces in the basal and intermediary layers were more narrow. Finger-like projections of basal and intermediary cells interfering into these spaces were shorter and thinner (Fig. 7). Numerous vacuoles occurred in the cellular cytoplasm of the upper part of the epithelium. It is a case of transitional cells that in this experimental group did not form a continual layer of cells. Vacuoles filled with ER protein did not merge into larger formations in the cytoplasm. Connection of cells by desmosomes was preserved.

Ultrastructure of the epithelium of ruminal mucosa in winter

In the basal part epithelium the wide intercellular spaces filled with abundant cytoplasmic projections as well as amorphous compound were observed. Transitional cells were found sporadically and dispersed among granular and keratinized cells. On the surface of keratinized cells a large quantity of ruminal bacteria and protozoa were found. A close connection among the cells of the granular and keratinized epithelial layer was ensured by preserved desmosomes (Fig. 6).

\section{Discussion}

The presented ultrastructure findings support the data on absorptive and secretory functions of the ruminal epithelium. Wide intercellular spaces with their morphological structure enlarge the cellular absorption area and thus enable a diffuse transfer of nutrients 
and orther substances (Hydén and Sperber 1965). The cytoplasmic projections in the stratum basale and intermediale have a close relationship to the basement membrane (Schnorr and Vollmerhaus 1967). Histochemically in the basal ruminal cells a minimum activity of acid phosphatase was recorded, but towards the epithelium surface it increased to reach a maximum in the stratum intermediale and stratum granulosum (B elák and Kočišová 1974). In these epithelial layers of ruminal mucosa metabolic processes take place as evidenced by abundance of cytoplasmic structures. Mitochondria are indicative of the physiological status of the cell so that high numbers of them are usually found in highly active cells with intensive metabolism. In this study, they were detected in argest numbers in basal, and predominantly intermediary cells in animals examined in the spring and summer. The highest activity of oxidative enzymes in these epithelial cells was found by Schulz (1962). Transitional cells with numerous vacuoles with ER proteins are also a parameter of metabolic processes (Henriksson and Habel 1961). Importance in the intracellular metabolism is also attributed to vacuoles. Occurrence of these structures in the cytoplasm of basal and intermediary cells is an evidence of active participation of the epithelial basal part in the cellular metabolism.

The keratinized layer of the epithelium fulfils also a protective function (Lavker and Matolts y 1970). In the animals studied in spring a large amount of protozoa and bacteria was found not only on its surface, but also within and underneath keratinized cells. In addition to their metabolic function, they also serve as a source of proteins. The activity of protozoa and bacteria result in changes of the mucosal relief in that it becomes more folded and the epithelial absorption area is enlarged. A higher layer of keratinized cells was found in winter. It was, no doubt, due to consumption of larger amounts of dry feed components.

According to Cheng et al. (1993) the content of ruminal bacteria is changing in dependence on seasons of the year. While in summer they found larger bacterial species, in winter the opposite was true. In our material, a more abundant occurrence of larger species of bacteria was found in spring, or the ratio of larger to smaller species was in favour of the former one. Based upon the evaluation of the rumen epithelial cells, their mitochondria numbers, endoplasmic reticulum, ER proteins and wide intercellular spaces with cytoplasmic projections as well as the findings of ruminal bacteria, clear differences were found in the epithelial structure of ruminal mucosa in spring, summer and partially autumn seasons. It is concluded that this is a result of mucosal adaptation to various types of diets.

\section{Acknowledgements}

We thank for technical assistance to Ing. M. Kokardová.

\section{References}

BARCROFT, I., ANNALY, R. A., PHILLIPSON, A. T. 1944: Absorption of volatile acids from alimentary tract of the sheep and other animals. J. Exptl. Biol. 20:120-129

BELÁK, M., KOČIŠOVÁ, J. 1973: Ultraštruktúra epitelu sliznice rumena jahniat počas ich postnatálneho vývoja. II. Stratum granulosum et corneum. Folia veter. 17:389-396

BELÁK, M., KOČIŠOVÁ, J. 1974: Histochemické štúdium aktivity kyslej fosfatázy v epiteli ruminálnej sliznice jahniat. Folia veter. 18:457-466

HENRIKSSON, K. B., HABEL, R. E. 1961: The morphology and sulfhydryl and disulfide reaction of the epithelium of the bovine forestomach during postnatal development. Anat. Rec. 139:499-507

HYDÉN, S., SPERBER, I. 1965: Physiology of digestion in the ruminant. (Eds. R. W. Dougherty, R. S. Allen, W. Bunoughs, N. L. Jacobson. A. D. McGilliard), London, Butterworth Co. Publishers Ltd.

CHENG, K. J., McALliSTER, T. A., MATHIESEN, S. D., BLIX, A. S., ORPIN, C. G., COSTERTON, J. W. 1993: Seasonal changes in the adherent microflora of the rumen in high-artic Svalbard reindeer. Can. J. Microbiol. 39:101-108 
KOČIŠOVÁ, J., BELÁK, M. 1973:Ultraštruktúra epitelu sliznice rumena jahniat počas ich postnatálneho vývoja. I. Stratum basale a intermediale. Folia veter. 17:381-388

KOČIŠOVÁ, J., BELÁK, M. 1974: Submikroskopická struktúra sliznice epitelu bachora prežúvavcov pri monodiéte. Veter. Cas. 16:139-144

LAVKER, R., MATOLTSY, G. 1970: Formation of horny cells. The fate of cell organelles and differentiation products in rumen epithelium. J. Cell. Biol. 44:501-512

REYNOLDS, E. S. 1963: The use of lead citrate at high pH as electron opaque stain in electron microscopy. J. Cell. Biol. 17: 208-212

SCHNORR, B., VOLLMERHAUS, B. 1967: Die Feinstruktur des Pansenepithels von Ziege und Rind. Zbl. veter. Med. 14: 784-818

SCHULZ, H. 1962: Histo-topochemische Enzym und Lipidbestimmungen and der Kutanen Vormagenmucosa von Camelus ferus F. bactrianus L. Zool. Anz. 169:440-448

WATSON, M. L. 1958: Staining of tissue sections for electron microscopy with heavy metals. J. Biophys. Biochem. Cytol. 4: 475-478 
Plate XVI.

Kočišová J.: Seasonal effects... pp. 231-234.

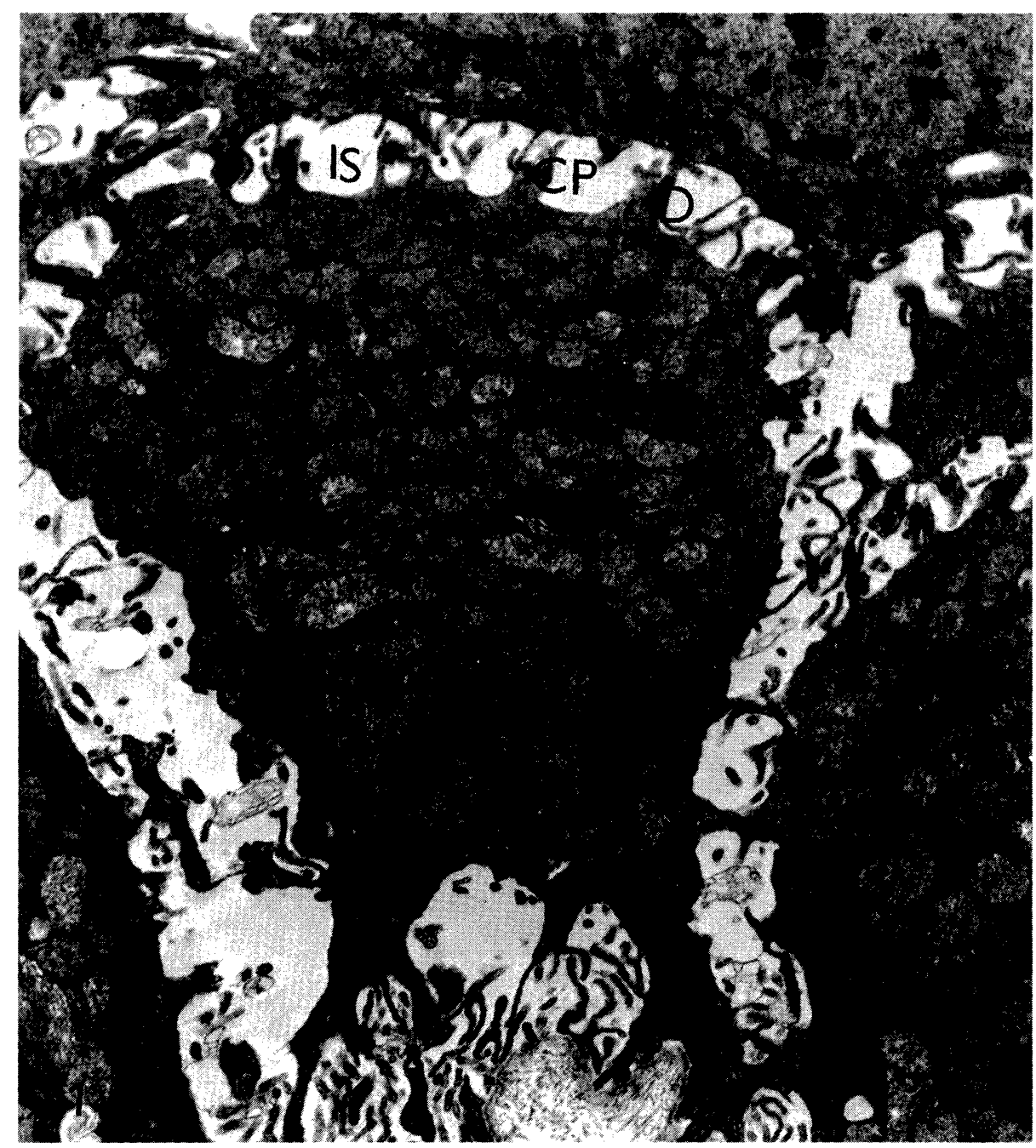

Fig. 1.: Basal part of the epithelium of ruminal mucosa. Spring sample. A high cylindrical cell with cytoplasm filled with large numbers of mitochondria (Mi) of various shapes, situated in the cellular supranuclear zone. Numerous cytoplasmic projections (CP) reach into the wide intercellular spaces (IS). Cytoplasmic projections of two cells are connected by desmosomes (D). 


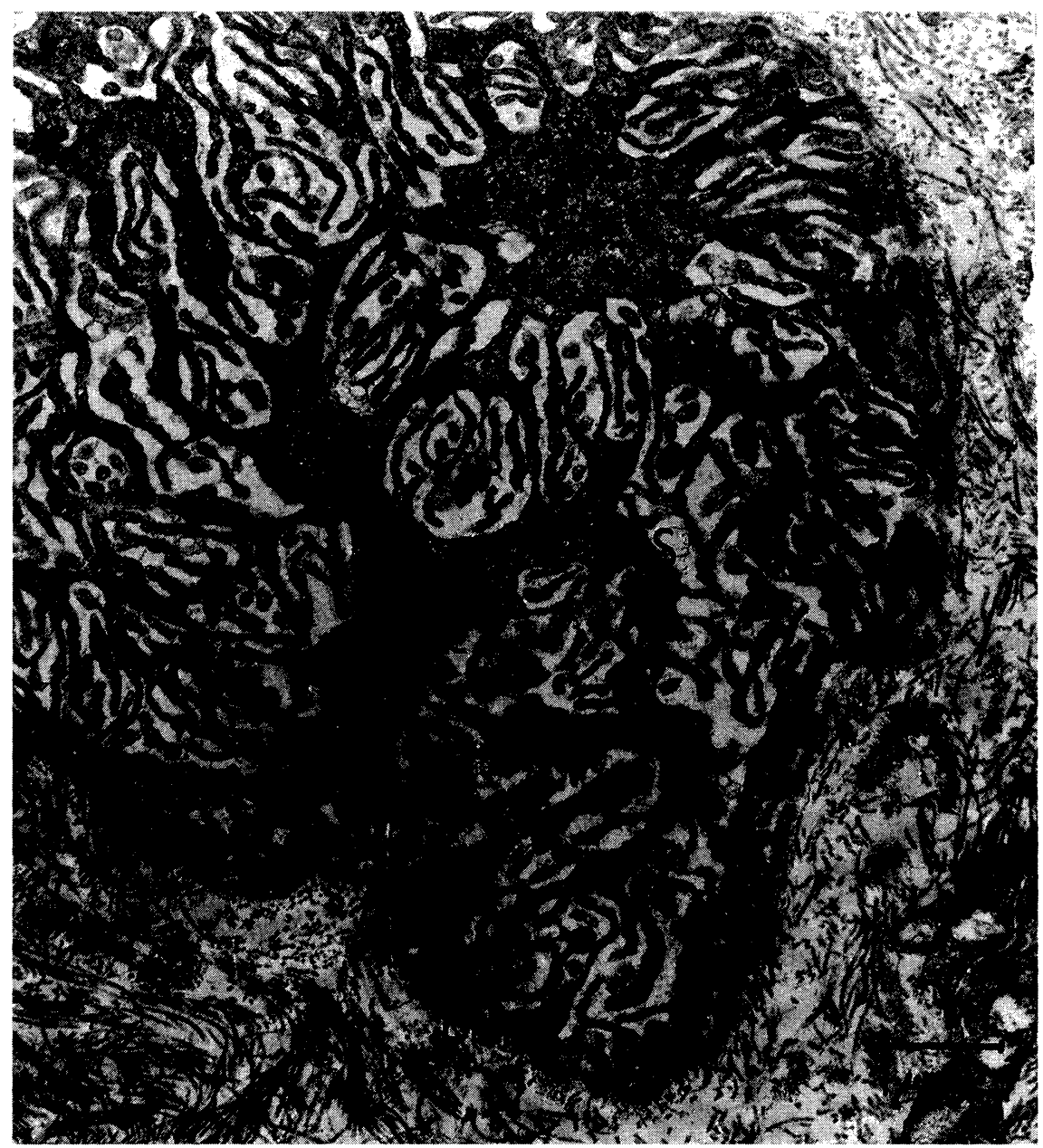

Fig. 2.: A transverse section through the basal and parabasal part of cells in the group of experimental animals Summer sample. There are numerous cytoplasmic projections (CP) in these cells. Wide intercellular spaces (IS) with cellular projections ensure active metabolic processes in the basal part of the epithelium. BM - basal membrane. 


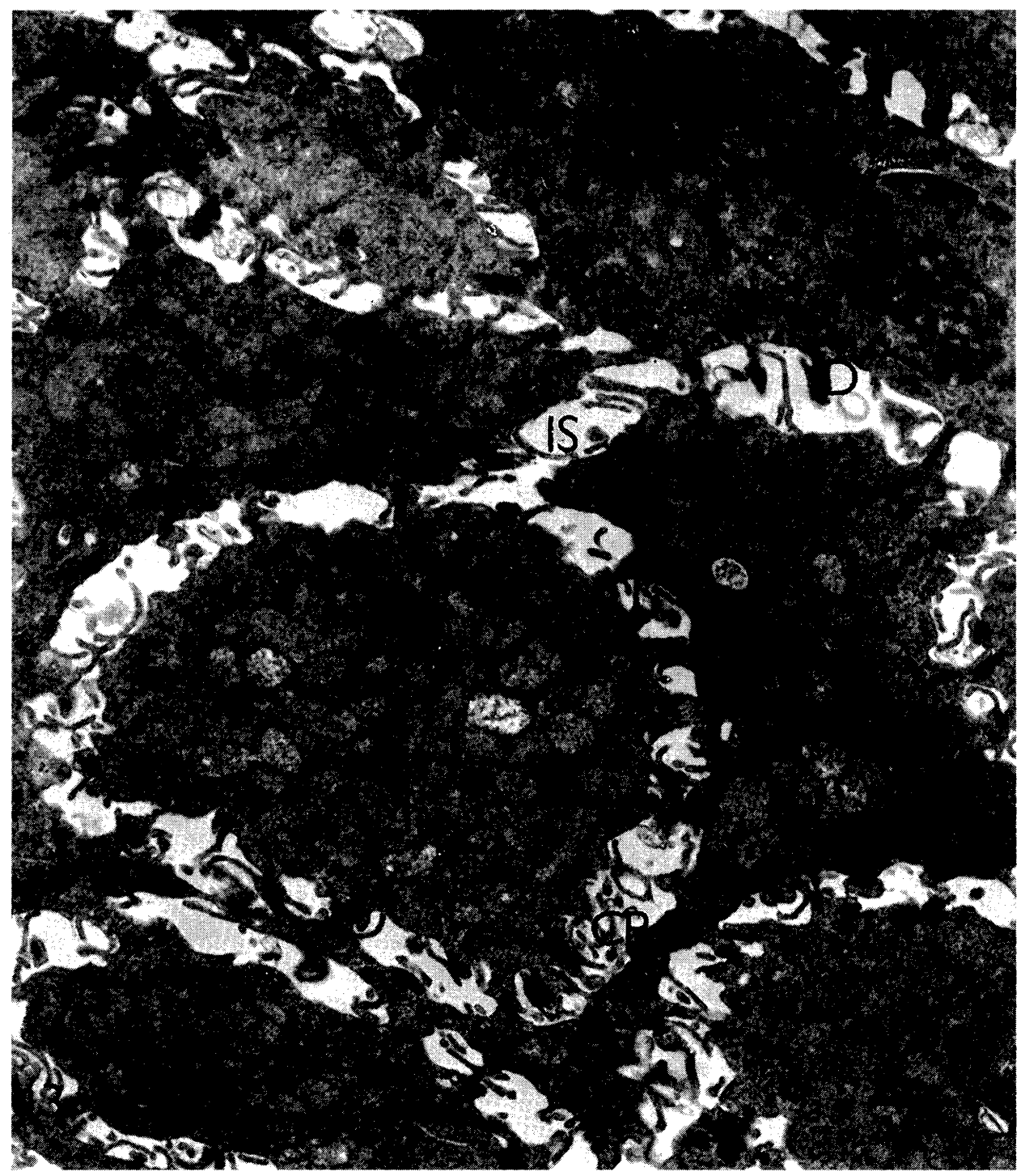

Fig. 3.: Section through the intermediary layer of epithelial cells of ruminal mucosa. Spring sample. 
Plate IXX.

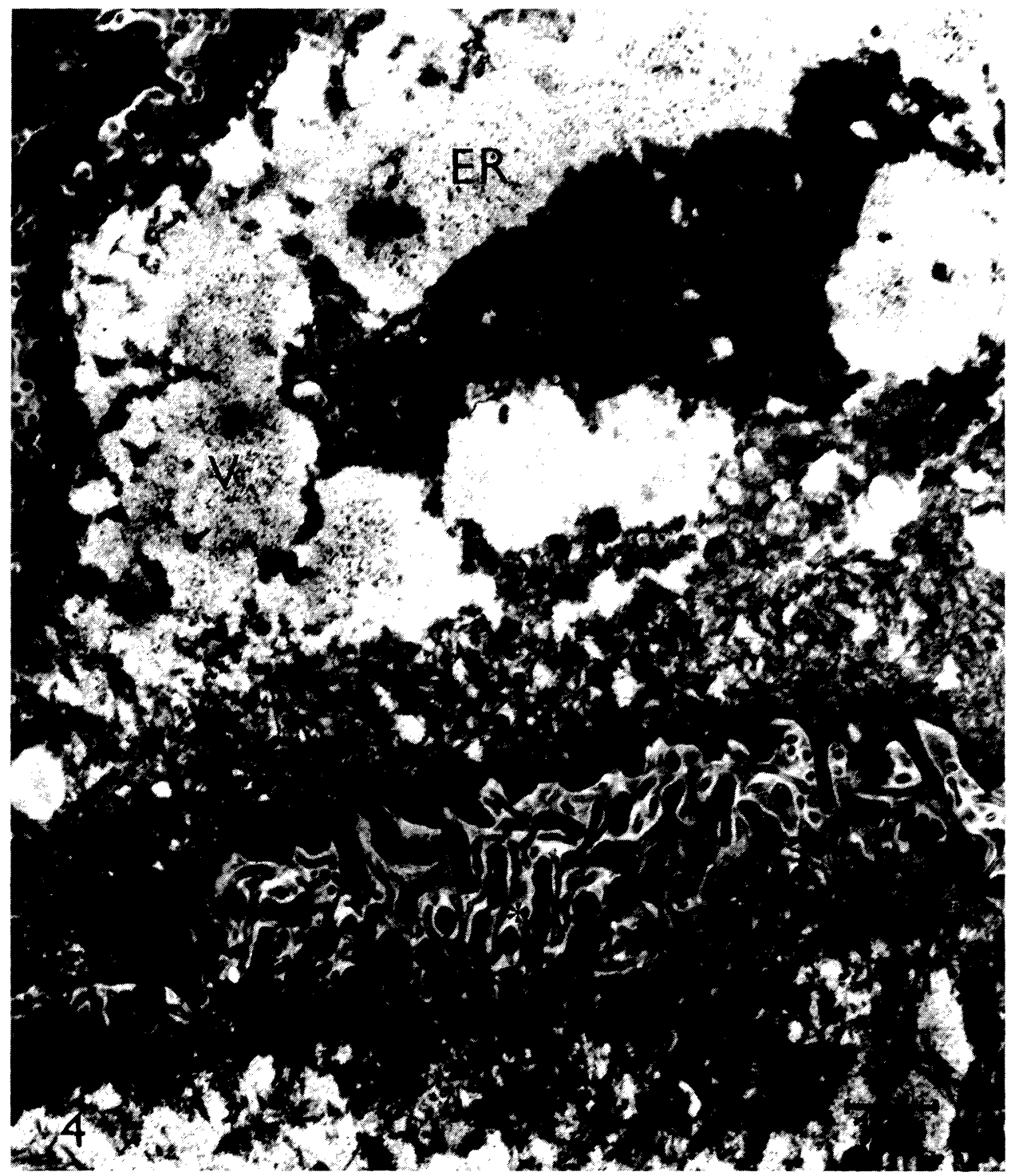

Fig. 4.: A part of the transitional cell (T). Spring sample. There are vacuoles $(V)$ in nuclei filled with ER protein. A marginal zone is filled with tonofilaments $(\mathrm{T})$. Intercellular spaces are narrow $(*)$. Cytoplasmic projections of adjoining cells fit very close to each other. 


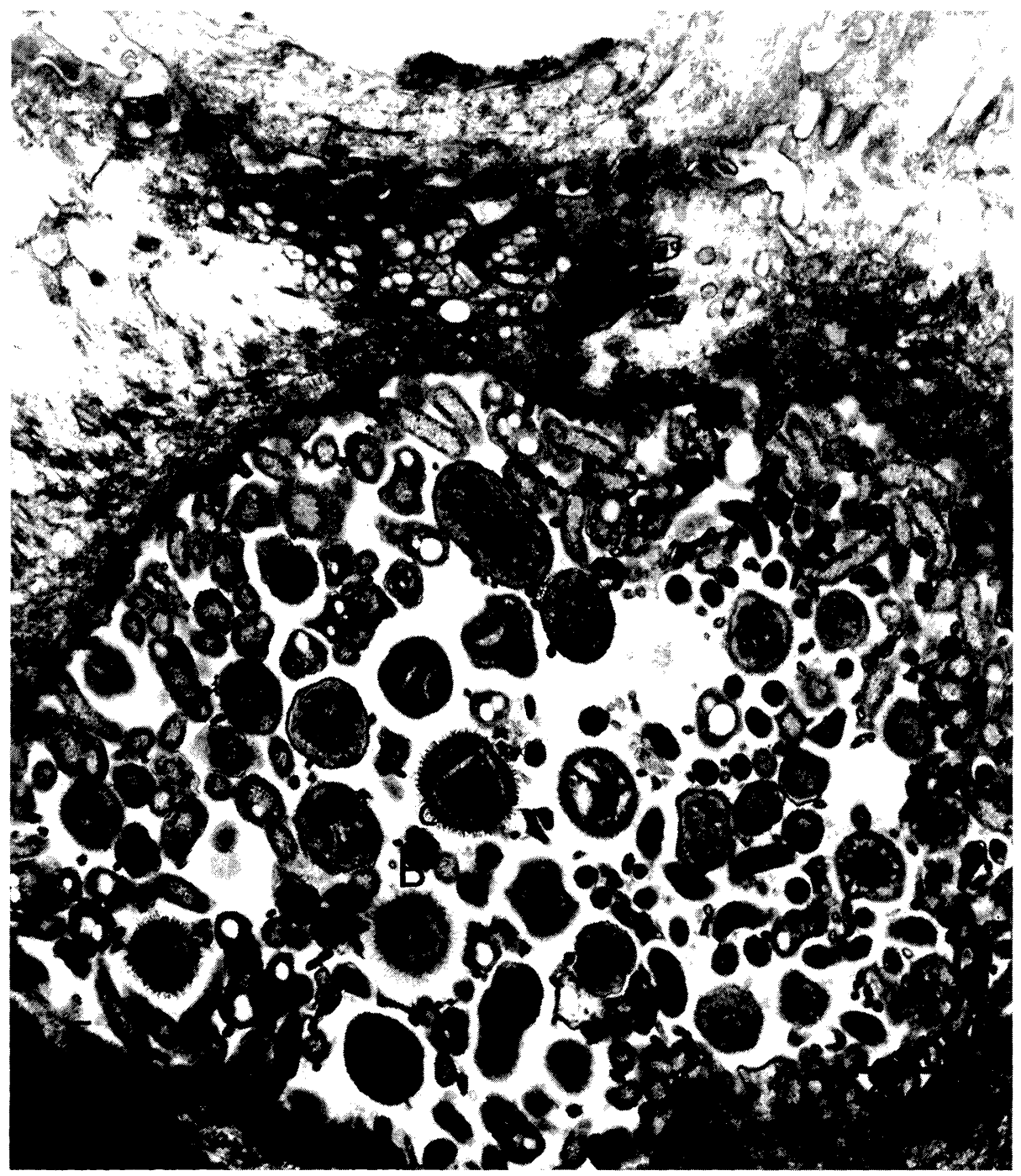

Fig. 5.: A superficial part of the ruminal mucosa epithelium. Spring sample. Various kinds of ruminal bacteria $(B)$ and protozoa $(\mathrm{P})$ with cilia $(\mathrm{c})$ are squeezed between keratinized epithelial cells. 


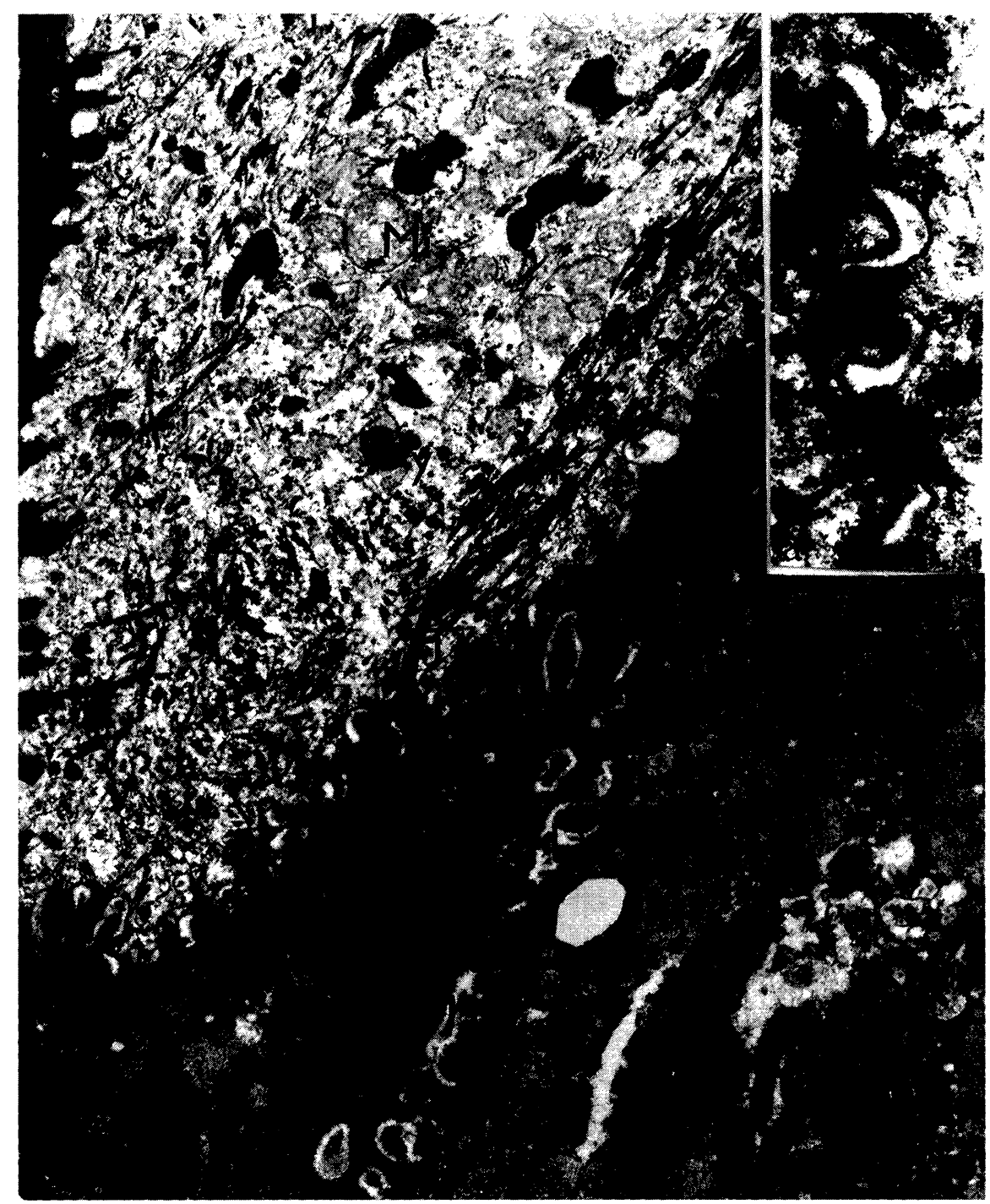

Fig. 6.: A keratinized part of the ruminal mucosa epithelium. Winter sample. Intercellalr space (IS) are slit-shapes. Short cytoplasmic projections (CP) of adjoining cells are connected by preserved desmosomes (D). Cytoplasm in the marginal part of a cell if filled with tonofibrils (T). In the middle of the cell there are vacuolized mitochondria (Mi) and lysosomes (Ly). Cells in the lower right corner are filled with keratinized mass (KM). a - there is enlargement of narrow intercellular spaces with desmosomes. 
Plate XXII.

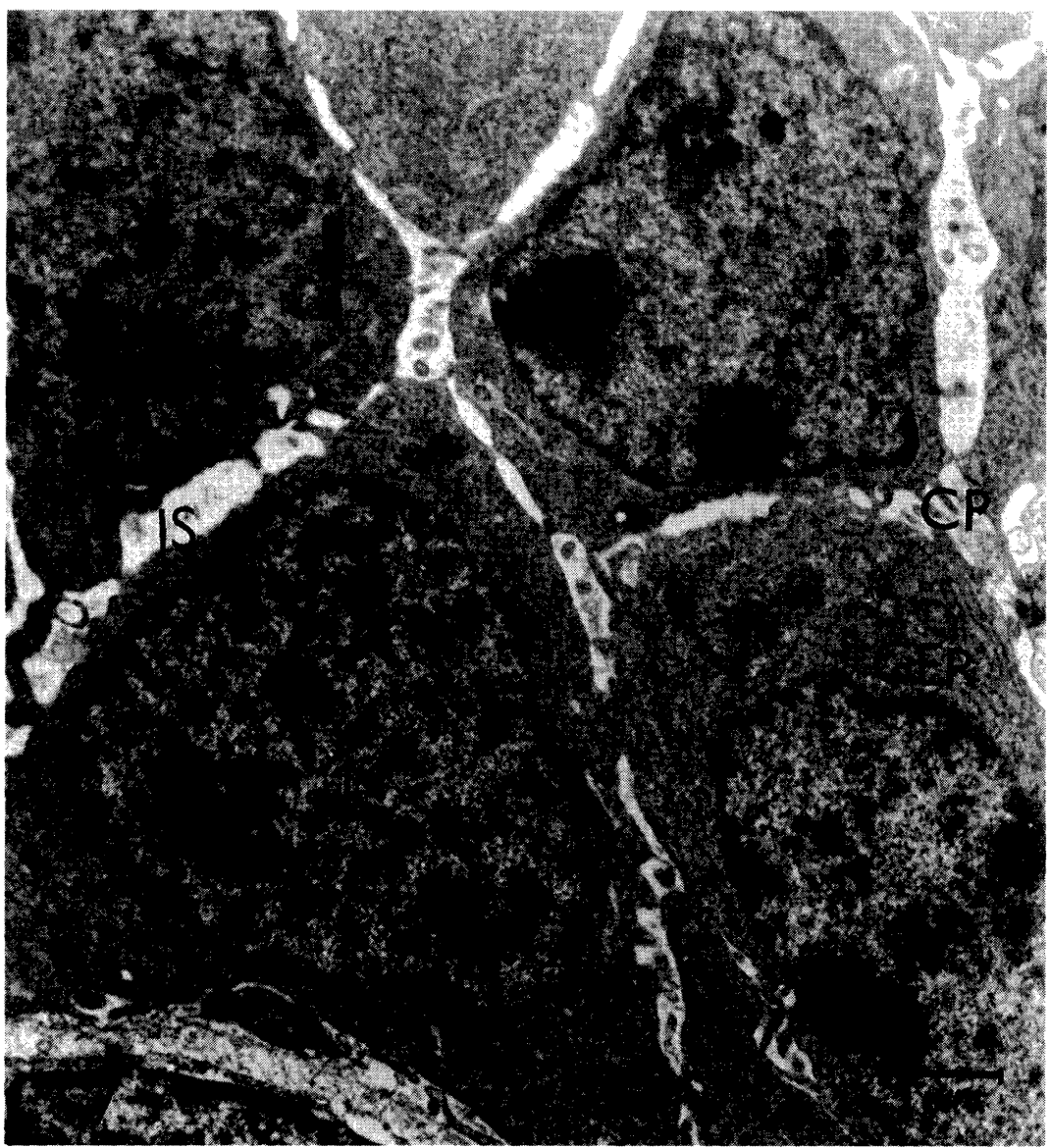

Fig. 7.: A longitudinal section through the basal layer of the epithelium. Autumn sample. A larger part of cells fills the nucleus (N). In cytoplasm there was the endoplasmic reticulum (GER) of granular type. Intercellular spaces (IS) are narrower, cytoplasmic projections are shorter and thinner. 